\title{
Unexploited willow's plantation (Salix viminalis) as a reservoir of epigeic ground beetles (Col., Carabidae) and rove beetles (Col., Staphylinidae)
}

\author{
Nieużytkowana plantacja wierzby wiciowej (Salix viminalis) \\ jako rezerwuar epigeicznych biegaczowatych (Col., Carabidae) \\ i kusakowatych (Col., Staphylinidae)
}

\author{
Karolina Konieczna ${ }^{1}$, Andrzej Melke², Tomasz Olbrycht ${ }^{1}$
}

\begin{abstract}
Summary
The species composition and abundance of ground beetles and rove beetles inhabiting unexploited willow's plantation (Salix viminalis) were investigated at four study sites in the suburban district of Rzeszów, Zalesie in 2011 and 2012. The beetles were caught using Barber's traps- at each site four traps were placed. As a result of the investigation, 1.532 beetles were collected, including 22 ground beetles and 50 rove beetles. Both ground beetles (Col., Carabidae) and rove beetles (Col., Staphylinidae) are considered useful entomofauna since they are natural enemies of many pests, and help regulate the number of harmful insects, thus results in providing environment resistance to phytophagous insects. Leaving in the ecosystem unnatural shrubberies, for example, willow plantations excluded from the use, creatses new habitats for coleopterofauna, including species that are not only useful but they also enrich enviroment by increasing number of species inhabiting wooded land. The study also shows the presence of very rare species of the Staphylinidae and protected representatvies of the genus Carabus. That observation confirms the assumption of conservation unused functions monocultures.
\end{abstract}

Key words: ground beetles, Carabidae, rove beetles, Staphylinidae, willow, unexploited plantation

\begin{abstract}
Streszczenie
Badania prowadzono na nieużytkowanej plantacji wierzby wiciowej (Salix viminalis) w Zalesiu, peryferyjnej dzielnicy położonej w południowej części Rzeszowa. Odłowy przeprowadzono w dwóch sezonach wegetacyjnych (2011 i 2012), stosując metodę pułapek glebowych Barbera. Na badanym terenie założono 4 pułapki. Zebrano ogółem 1532 chrząszcze, wśród których odnotowano 22 gatunki biegaczowatych i 50 kusakowatych. Zarówno biegaczowate (Carabidae), jak i kusakowate (Staphylinidae) są uznawane za pożyteczną entomofaunę, gdyż będąc naturalnymi wrogami wielu agrofagów, regulują liczebność szkodliwych organizmów stanowiąc tym samym istotny element oporu środowiska. Pozostawienie w ekosystemie sztucznych zakrzewień, jakimi mogą być np. wyłączone z użytkowania plantacje wikliny, stwarza nowe miejsca bytowania pożytecznej koleopterofauny, a także wzbogaca środowisko w gatunki związane z zadrzewieniami. Badania wykazały również obecność bardzo rzadkich gatunków z rodziny kusakowatych, jak i chronionych przedstawicieli rodzaju Carabus, co potwierdza założenie o funkcji konserwatorskiej nieużytkowanych monokultur.
\end{abstract}

Słowa kluczowe: biegaczowate, Carabidae, kusakowate, Staphylinidae, wierzba wiciowa, nieużytkowana plantacja

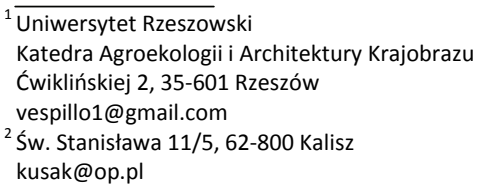




\section{Wstęp / Introduction}

Obserwowany w ostatnich latach wzrost zainteresowania roślinami energetycznymi jest efektem poszukiwania nowych źródeł energii. Plantacje roślin alternatywnych takich, jak: topinambur, miskant czy wierzba, oprócz istotnych aspektów ekonomiczno-energetycznych pełnią także istotne funkcje ekologiczne. Szczukowski i wsp. (1998) zaliczają do nich m.in. ochronę gleb przez zagospodarowywanie terenów zdewastowanych i odłogów, ochronę wód tworząc strefy buforowe wokół ujęć wody oraz ochronę powietrza tworząc barierę wzdłuż ciagów komunikacyjnych. Równie cenne jest występowanie w tym środowisku owadów pożytecznych (drapeżców i pasożytów), które odgrywają istotną rolę w ograniczaniu liczebności szkodliwej entomofauny. Występowanie agrofagów jest jedną $\mathrm{z}$ cech charakteryzujących monokultury, a jednocześnie determinującą ich plonowanie. $\mathrm{Na}$ szczególną uwagę zasługują chrząszcze biegaczowate (Carabidae) i kusakowate (Staphylinidae), które w przypadku licznego występowania mogą stanowić istotny element oporu środowiska wobec gatunków fitofagicznych zagrażających uprawom (Sądej i wsp. 1997; Sądej i wsp. 2007; Waleryś i wsp. 2008). Chrząszcze z tych rodzin pełnią także funkcję bioindykatorów, co może pozwolić na lepsze poznanie cech środowiska przyrodniczego oraz obserwację zmian w biocenozie wywołanych czynnikami antropogenicznymi (Boháč 1999; Szyszko 2002).

Efektem zainteresowania pożyteczną, epigeiczną karabidofauną zasiedlającą krajowe plantacje wierzb są m.in. prace Walerysia i wsp. (2008), Czerniakowskiego i Olbrychta (2009) oraz Kosewskiej i wsp. (2010). W Europie Środkowej takie badania były przeprowadzone np. w Niemczech (Mast i wsp. 2012) oraz w Republice Czeskiej (Š́t’astná 2012).

Znacznie słabiej przedstawia się stan poznania chrząszczy kusakowatych. Pomimo znacznego postępu w badaniach, ta najliczniejsza $\mathrm{w}$ gatunki rodzina chrząszczy jest nadal poznana fragmentarycznie (Staniec 2004). Tereny antropogeniczne, w tym agrocenozy, nie zostały jeszcze dostatecznie zbadane. $\mathrm{Z}$ nowszych prac zajmujących się tym tematem można wymienić opracowania Olbrychta i Wiecha (2004), Koniecznej i Czerniakowskiego (2010), Koniecznej i wsp. (2012).

Istotny wkład w tej dziedzinie wnoszą badania Jahnová i Boháč (2009, 2011), którzy opisali Carabidae i Staphylinidae, zasiedlające plantacje szybko rosnących traw i ziół uprawianych na cele energetyczne. Na szczególną uwagę zasługuje praca Boháč i wsp. (2007), opisująca biegaczowate i kusakowate $\mathrm{w}$ różnych typach plantacji roślin energetycznych, gdzie jednym ze stanowisk badawczych była plantacja drzew (topoli, wierzby i olchy).

Celem badań było przedstawienie aktualnego składu gatunkowego chrząszczy z rodzin biegaczowatych i kusakowatych zasiedlających wyłączoną z użytkowania plantację wierzby wiciowej (Salix viminalis). Praca stanowi również porównanie obserwacji prowadzonych przez Czerniakowskiego i Olbrychta (2009) na tym samym terenie, w okresie gdy plantacja była wykorzystywana na cele energetyczne. Jest to pierwsza w skali kraju próba opisania struktury ilościowo-jakościowej Staphylinidae występujących na plantacji S. viminalis.

\section{Materiały i metody / Materials and methods}

Odłowy prowadzono w dwóch sezonach wegetacyjnych (2011 i 2012) na wyłączonej z użytkowania plantacji wierzby wiciowej (S. viminalis) zlokalizowanej w południowej części Rzeszowa, dzielnicy Zalesie (UTM EA73). Powierzchnia badanej plantacji wynosiła 15 arów, a ostatnie cięcie wikliny miało miejsce w 2003 roku. W celu pozyskania materiału badawczego zastosowano metodę pułapek glebowych Barbera, które stanowiły plastikowe pojemniki o pojemności $400 \mathrm{ml}$, wkopane równo z powierzchnią gleby. W 2011 roku pobrano 11 prób, a w 2012 roku - 12 .

Układ systematyczny i nomenklaturę biegaczowatych przyjęto zgodnie z opracowaniem Stachowiaka (2008), zaś kusakowatych za Assing i Schülke (2012). Strukturę dominacji (d) opisano przyjmując klasy dominacji zaproponowane przez Kasprzaka i Niedbałę (1981). Opracowując wyniki posłużono się wskaźnikami ogólnej różnorodności gatunkowej Shannona-Weavera (H'), równomierności Pielou (J') oraz bogactwa gatunkowego Margalefa (D). Charakterystykę ekologiczną biegaczowatych przyjęto w oparciu o prace Burakowskiego i wsp. $(1973,1974)$ oraz Leśniaka (1984), zaś charakterystykę zoogeograficzną według Leśniaka (1987). Charakterystykę ekologiczną kusakowatych podano według Burakowskiego i wsp. (1979, 1980, 1981), Szujeckiego (2008) oraz obserwacje własne drugiego $\mathrm{z}$ autorów.

\section{Wyniki i dyskusja / Results and discussion}

Ogółem zebrano 1532 chrząszcze, z czego 937 stanowiły biegaczowate, zaś 595 kusakowate (tab. 1). W 2011 roku zaobserwowano łącznie 723 osobniki, podczas kiedy w roku następnym ich liczba wyniosła 809 okazów. Rodzinę biegaczowatych w 2011 roku reprezentowało 426 osobników, zaklasyfikowanych do 8 rodzajów i 16 gatunków, a w 2012 roku było to 511 chrząszczy należących do 9 rodzajów i 18 gatunków.

Struktura dominacji biegaczowatych oraz charakterystyka ekologiczna zostały przedstawione w tabeli 2 . Klasy dominacji, które potwierdzają stabilność populacji (eudominanty i dominanty), w obydwu sezonach badawczych tworzyły te same gatunki, z niewielkimi fluktuacjami liczebności. Najliczniej występowały Pterostichus melanarius (Ill.), P. niger (Schall.) oraz Limodromus assimilis (Payk.). P. melanarius (Ill.) jako eudominant został także wykazany $\mathrm{w}$ badaniach prowadzonych przez Walerysia i wsp. (2008), Czerniakowskiego i Olbrychta (2009) oraz Kosewską i wsp. (2010), natomiast występowanie L. assimilis (Payk.) w tej samej klasie dominacji potwierdzają Boháč i wsp. (2007) oraz Št’astná (2012). Można zatem traktować te gatunki jako stały komponent karabidofauny zasiedlającej plantacje wikliny wiciowej (S. viminalis). Klasę dominantów reprezentował tylko 
Tabela 1. Liczebność chrząszczy zebranych na nieużytkowanej plantacji wierzby wiciowej (S. viminalis)

Table 1. The number of beetles according to their abundance on unexploited willow's plantation (S. viminalis)

\begin{tabular}{l|c|c|c|c|c|c}
\hline & \multicolumn{2}{|c|}{ Liczba okazów - No. of specimens } & \multicolumn{2}{c|}{ Liczba gatunków - No. of species } & \multicolumn{2}{c}{ Liczba rodzajów - No. of genuses } \\
\hline Rodzina - Family & 2011 & 2012 & 2011 & 2012 & 2011 & 2012 \\
\hline Carabidae & 426 & 511 & 16 & 18 & 8 & 9 \\
\hline Staphylinidae & 297 & 298 & 43 & 24 & 24 & 14 \\
\hline Suma - Total & 723 & 809 & 40 & 42 & 32 & 23 \\
\hline
\end{tabular}

Tabela 2. Struktura dominacji i charakterystyka ekologiczna Carabidae odłowionych w dwóch sezonach wegetacyjnych

Table 2. Dominance structure and ecological characteristics of Carabidae caught in two growing seasons

\begin{tabular}{|c|c|c|c|c|c|c|c|c|}
\hline \multirow[t]{2}{*}{$\begin{array}{l}\text { Lp. } \\
\text { No. }\end{array}$} & \multirow[t]{2}{*}{$\begin{array}{l}\text { Gatunek } \\
\text { Species }\end{array}$} & \multicolumn{5}{|c|}{$\begin{array}{l}\text { Charakterystyka ekologiczna } \\
\text { Ecological characteristic }\end{array}$} & \multicolumn{2}{|c|}{$\begin{array}{c}\text { Struktura dominacji } \\
\text { odłowionych chrząszczy d } \\
\text { Dominance structure of } \\
\text { caught beatles d } \\
{[\%]}\end{array}$} \\
\hline & & I & II & III & IV & $\mathrm{V}$ & 2011 & 2012 \\
\hline 1 & Nebria brevicollis (F.) & $\mathrm{L}$ & $\mathrm{Zm}$ & $\mathrm{Mh}$ & $\mathrm{J}$ & Ear & 4,5 & 4,9 \\
\hline 2 & Notiophilus palustris (Duft.) & $\mathrm{L}$ & $\mathrm{Zm}$ & Wilg & $\mathrm{W}$ & Pal & 0,2 & - \\
\hline 3 & Carabus granulatus L. & ToiZ & $\mathrm{Zd}$ & Wilg & $\mathrm{W}$ & Esyb & 2,6 & 3,2 \\
\hline 4 & C. ulrichii Germar & To & $\mathrm{Zd}$ & $\mathrm{Mh}$ & $\mathrm{W}$ & Esyb & 7,5 & 7,1 \\
\hline 5 & C. violaceus (L.) & $\mathrm{L}$ & $\mathrm{Zd}$ & $\mathrm{Mh}$ & $\mathrm{W}$ & Pal & 1,9 & 2,5 \\
\hline 6 & C. coriaceus $\mathrm{L}$. & $\mathrm{L}$ & $\mathrm{Zd}$ & $\mathrm{Mh}$ & $\mathrm{J}$ & EPL & 0,9 & 0,9 \\
\hline 7 & Asaphidion flavipes (L.) & To & $\mathrm{Zm}$ & $\mathrm{Mh}$ & $\mathrm{W}$ & Pal & - & 0,2 \\
\hline 8 & Metallina lampros (Herbst) & To & $\mathrm{Zm}$ & $\mathrm{Mh}$ & $\mathrm{W}$ & Pal & 0,7 & - \\
\hline 9 & Harpalus rufipes (De Geer) & To & $\mathrm{Hz}$ & $\mathrm{Mh}$ & $\mathrm{J}$ & Pal & 4,9 & 3,3 \\
\hline 10 & H. latus (L.) & $\mathrm{L}$ & $\mathrm{Hz}$ & $\mathrm{Mh}$ & $\mathrm{W}$ & Pal & 0,7 & 0,8 \\
\hline 11 & Pterostichus sp. & - & - & - & - & - & - & 0,4 \\
\hline 12 & P. vernalis (Panz.) & ToiZ & $\mathrm{Zm}$ & Wilg & $\mathrm{W}$ & Pal & 0,7 & 0,8 \\
\hline 13 & P. niger (Schall.) & $\mathrm{L}$ & $\mathrm{Zd}$ & $\mathrm{Mh}$ & $\mathrm{J}$ & Esyb & 24,8 & 27,2 \\
\hline 14 & P. melanarius (Ill.) & ToiZ & $\mathrm{Zd}$ & $\mathrm{Mh}$ & W & Esyb & 26,1 & 30,3 \\
\hline 15 & P. anthracinus (Ill.) & ToiZ & $\mathrm{Zm}$ & $\mathrm{Mh}$ & $\mathrm{J}$ & Pal & - & 0,9 \\
\hline 16 & P. ovoideus (Sturm) & To & $\mathrm{Zm}$ & Wilg & $\mathrm{W}$ & Esyb & - & 0,4 \\
\hline 17 & Abax parallelepipedus (Pill. Et Mitt.) & $\mathrm{L}$ & $\mathrm{Zd}$ & Wilg & $\mathrm{W}$ & Esyb & 0,7 & - \\
\hline 18 & A. parallelus (Duft.) & $\mathrm{L}$ & $\mathrm{Zd}$ & Wilg & $\mathrm{J}$ & Esyb & 2,6 & - \\
\hline 19 & A. carinatus (Duft.) & $\mathrm{L}$ & $\mathrm{Zm}$ & $\mathrm{Mh}$ & $\mathrm{J}$ & GEPL & 0,5 & 1,2 \\
\hline 20 & Calathus fuscipes Goeze & To & $\mathrm{Zm}$ & Wilg & $\mathrm{J}$ & Pal & - & 0,4 \\
\hline 21 & Limodromus assimilis (Payk.) & $\mathrm{L}$ & $\mathrm{Zm}$ & Wilg & $\mathrm{W}$ & Pal & 20,6 & 15,2 \\
\hline 22 & Amara aulica (Panz.) & To & $\mathrm{Hz}$ & Mh & W & Pal & - & 0,2 \\
\hline \multicolumn{7}{|c|}{ Wskaźnik Margalefa D - Margalef's index D } & 0,77 & 0,87 \\
\hline \multicolumn{7}{|c|}{ Różnorodność gatunkowa (H’) - Shannon’ diversity (H’) } & 1,72 & 1,70 \\
\hline \multicolumn{7}{|c|}{ Równomierność - Evenness H/log(N) Pielou (J') } & 0,43 & 0,42 \\
\hline
\end{tabular}

Charakterystyka ekologiczna - Ecological characteristic:

I - środowisko życia - habitat: L - las - forest, ToiZ - tereny otwarte i zadrzewienia - open area and wooded land, To - tereny otwarte - open area, $\mathrm{Nw}$ - tereny nadwodne - riparian

II - grupa troficzna - feeding habits: Zd - duże zoofagi - large zoophages, Zm - małe zoofagi - small zoophages, Hz - hemizoofagi - hemizoophages

III - higropreferencje - higropreferences: Wilg - wilgociolubny - hygrophilous, $\mathrm{Mh}$ - mezohigrofilny - mesophilous, $\mathrm{S}$ - sucholubny - xerophilous

IV - fenologia - phenology: W - wiosenny - spring, J - jesienny - autumn

V - charakterystyka zoogeograficzna - zoogeographical characteristic: Pal - palearktyczny - palearctic, Ear - euroartktyczny - Euro-Arctic, Esyb - euro syberyjski - Euro-Siberian, GEPL - górska europejska prowincja leśna - European Forest Province Montane

Carabus ulrichii Germar, przedstawiciel dużych zoofagów. Wykazany został on także przez Czerniakowskiego i Olbrychta (2009), co mając na uwadze lokalny charakter zasięgu tego taksonu, pozwala wnioskować o stałości populacji tego gatunku na badanym terenie. Do subdominatów zaliczono 5 gatunków, przy czym Nebria 
Tabela 3. Struktura dominacji i charakterystyka ekologiczna Staphylinidae odłowionych w dwóch sezonach wegetacyjnych Table 3. Dominance structure and ecological characteristics of Staphylinidae caught in two growing seasons

\begin{tabular}{|c|c|c|c|c|c|c|}
\hline \multirow[t]{2}{*}{$\begin{array}{l}\text { Lp. } \\
\text { No. }\end{array}$} & \multirow[t]{2}{*}{$\begin{array}{l}\text { Gatunek } \\
\text { Species }\end{array}$} & \multicolumn{3}{|c|}{$\begin{array}{l}\text { Charakterystyka ekologiczna } \\
\text { Ecological characteristic }\end{array}$} & \multicolumn{2}{|c|}{$\begin{array}{c}\text { Struktura dominacji } \\
\text { odłowionych chrząszczy d } \\
\text { Dominance structure } \\
\text { of caught beatles d } \\
{[\%]}\end{array}$} \\
\hline & & I & II & III & 2011 & 2012 \\
\hline 1 & 2 & 3 & 4 & 5 & 6 & 7 \\
\hline 1 & Anthobium atrocephalum (Gyll.) & ek & Hol & $\mathrm{S}$ & 0,7 & - \\
\hline 2 & Omalium caesum Grav. & $\mathrm{kn}$ & Hol & $\mathrm{S}$ & 0,3 & - \\
\hline 3 & O. rivulare (Payk.) & $\mathrm{k}$ & Hol & $\mathrm{S}$ & 14,5 & 5,4 \\
\hline 4 & O. septentrionis Thoms. & $\mathrm{K}$ & Pal & $\mathrm{S}$ & 0,7 & 0,3 \\
\hline 5 & Proteinus brachypterus (F.) & $\mathrm{gk}$ & Pal & $\mathrm{S}$ & 0,3 & - \\
\hline 6 & Lordithon lunulatus (L.) & $\mathrm{g}$ & Pal & $\mathrm{M}$ & 0,3 & - \\
\hline 7 & Sepedophilus marshami (Steph.) & degk & $\mathrm{E}$ & MS & 0,3 & - \\
\hline 8 & S. testaceus $(\mathrm{F})$. & dgk & Hol & MS & 0,7 & - \\
\hline 9 & Tachinus corticinus Grav. & ek & Pal & $\mathrm{S}$ & 0,7 & - \\
\hline 10 & T. laticollis Grav. & ek & Pal & $\mathrm{S}$ & - & 0,3 \\
\hline 11 & T. pallipes (Grav.) & ek & Hol & $\mathrm{S}$ & 0,3 & - \\
\hline 12 & T. rufipes (L.) & ek & Hol & $\mathrm{S}$ & 1,1 & 1,7 \\
\hline 13 & Tachyporus abdominalis (F.) & ek & Hol & $\mathrm{MZ}$ & 3,3 & 0,3 \\
\hline 14 & T. dispar (Payk.) & ek & $\mathrm{E}$ & $\mathrm{MZ}$ & 0,3 & - \\
\hline 15 & T. nitidulus (F.) & ekn & Hol & MZ & - & 0,3 \\
\hline 16 & T. pusillus Grav. & $\mathrm{e}$ & Pal & $\mathrm{MZ}$ & 0,3 & - \\
\hline 17 & T. solutus Er. & Ek & Pal & $\mathrm{MZ}$ & 0,3 & - \\
\hline 18 & Aleochara curtula (Goeze) & $\mathrm{k}$ & Kos & $\mathrm{ZP}$ & 7,7 & 9,8 \\
\hline 19 & Atheta crassicornis (F.) & $\mathrm{g}$ & $\mathrm{Pal}$ & MS & - & 1,7 \\
\hline 20 & A. ravilla $($ Er.) & $\mathrm{gk}$ & $\mathrm{E}$ & MS & 0,3 & - \\
\hline 21 & Drusilla canaliculata $(\mathrm{F})$. & ek & Pal & $\mathrm{Z}$ & 6,4 & 10,4 \\
\hline 22 & Ilyobates nigricollis (Payk.) & es & $\mathrm{E}$ & $\mathrm{Z}$ & 0,3 & - \\
\hline 23 & Oxypoda acuminata (Steph.) & $\mathrm{ek}$ & Pal & $\mathrm{Z}$ & 4,8 & 2,7 \\
\hline 24 & O. spectabilis Märkel & ekn & Pal & $\mathrm{Z}$ & - & 0,3 \\
\hline 25 & Anotylus inustus (Grav.) & $\mathrm{k}$ & $\mathrm{Pal}$ & $\mathrm{S}$ & 0,3 & - \\
\hline 26 & A. mutator (Lohse) & $\mathrm{k}$ & Pal & $\mathrm{S}$ & 4,7 & 1,4 \\
\hline 27 & A. rugifrons (Hoch.) & $\mathrm{k}$ & $E$ & $\mathrm{~S}$ & 0,3 & - \\
\hline 28 & A. rugosus (F.) & $\mathrm{ek}$ & $\mathrm{Pal}$ & $\mathrm{S}$ & 0,3 & - \\
\hline 29 & A. sculpturatus (Grav.) & $\mathrm{k}$ & Pal & $\mathrm{S}$ & 1,1 & 1,0 \\
\hline 30 & Ochthephilum fracticorne (Payk.) & $\mathrm{k}$ & Pal & $\mathrm{Z}$ & 0,3 & - \\
\hline 31 & Paederus litoralis Grav. & $\mathrm{e}$ & $\mathrm{E}$ & $\mathrm{Z}$ & 0,3 & 0,3 \\
\hline 32 & Rugilus rufipes (Germar) & ek & $\mathrm{E}$ & $\mathrm{Z}$ & 0,7 & - \\
\hline 33 & Othius punctulatus (Goeze) & $\mathrm{e}$ & Pal & Z & 1,1 & - \\
\hline 34 & Bisnius fimetarius (Grav.) & $\mathrm{k}$ & Pal & $\mathrm{Z}$ & - & 0,3 \\
\hline 35 & Ocypus nitens (Schrank) & $\mathrm{e}$ & $\mathrm{E}$ & $\mathrm{Z}$ & - & 0,3 \\
\hline 36 & Ontholestes tesselatus (Geoffr.) & $\mathrm{e}$ & $\mathrm{E}$ & $\mathrm{Z}$ & 0,3 & - \\
\hline 37 & Philonthus addendus Sharp & $\mathrm{k}$ & Pal & $\mathrm{Z}$ & 12,5 & 33,9 \\
\hline 38 & P. concinnus (Grav.) & $\mathrm{k}$ & Pal & $\mathrm{Z}$ & 0,3 & - \\
\hline 39 & P. decorus (Grav.) & $\mathrm{gk}$ & $\mathrm{E}$ & $\mathrm{Z}$ & 14,8 & 13,8 \\
\hline 40 & P. mannerheimi Fauv. & Gk & $\mathrm{Hol}$ & $\mathrm{Z}$ & 0,3 & - \\
\hline 41 & P. pseudovarians Strand & $\mathrm{k}$ & $\mathrm{E}$ & $\mathrm{Z}$ & 0,3 & 0,6 \\
\hline 42 & P. rotundicollis (Ménétries) & ek & Pal & $\mathrm{Z}$ & - & 0,3 \\
\hline
\end{tabular}




\begin{tabular}{c|l|c|c|c|c|c}
\hline \multicolumn{1}{|c|}{2} & 3 & 4 & 5 & 6 & 7 \\
\hline 43 & P. succicola Thoms. & $\mathrm{K}$ & $\mathrm{Pal}$ & $\mathrm{Z}$ & 11,1 & 12,8 \\
\hline 44 & P. tenuicornis Mulsant \& Rey & $\mathrm{gk}$ & $\mathrm{Pal}$ & $\mathrm{Z}$ & 3,1 & 0,6 \\
\hline 45 & Platydracus fulvipes (Scop.) & $\mathrm{e}$ & $\mathrm{Pal}$ & $\mathrm{Z}$ & 0,3 & - \\
\hline 46 & Quedius fuliginosus (Grav.) & $\mathrm{e}$ & $\mathrm{Pal}$ & $\mathrm{Z}$ & 1,1 & - \\
\hline 47 & Staphylinus erythropterus L. & $\mathrm{e}$ & $\mathrm{Hol}$ & $\mathrm{Z}$ & 1,1 & 0,6 \\
\hline 48 & Tasgius melanarius (Heer) & $\mathrm{ek}$ & $\mathrm{E}$ & $\mathrm{Z}$ & 1,4 & 0,6 \\
\hline 49 & T. morsitans (Rossi) & $\mathrm{ek}$ & $\mathrm{E}$ & $\mathrm{Z}$ & 0,3 & - \\
\hline 50 & Gyrohypnus punctulatus (Payk.) & $\mathrm{k}$ & $\mathrm{Pal}$ & $\mathrm{Z}$ & 0,3 & - \\
\hline Wskaźnik Margalefa D - Margalef's index D & & & & 1,90 & 1,06 \\
\hline Różnorodność gatunkowa (H') - Shannon' diversity (H') & & & & 0,45 \\
\hline Równomierność - Evenness H/log(N) Pielou (J')
\end{tabular}

Charakterystyka ekologiczna - Ecological characteristic:

I - preferencje mikrosiedliskowe - microsite preferences:

d - gatunki podkorowe - underbark species, e - gatunki epigeiczne - epigeic species, g - gatunki grzybo i próchnolubne - fungi and wood-decay fungus species, $\mathrm{k}$ - gatunki detrytofilne (związane z rozkładającą się substancją organiczną, kompostem lub padliną) - connected with decaying organic matter, compost and/or carcass, $\mathrm{n}$ - gatunki nor lub gniazd (nidikole) - species living in hollows or nests (nidicolous)

II - charakterystyka zoogeograficzna - zoogeographical characteristic: Pal - palearktyczny - palaearctic, E - europejski - european, Hol - holarktyczny

- holarctic, Kos - kosmopolityczny - cosmopolitan

III - grupa troficzna - feeding habits

$\mathrm{M}$ - mycetofag - mycetophagoust, $\mathrm{S}$ - saprofag - saprophagous, Z - zoofag - zoophagous, ZP - parazytoid - parasitoid

brevicollis (F.), Harpalus rufipes (De Geer) oraz Carabus granulatus L. były wspólne w obydwu sezonach wegetacyjnych. Oprócz gatunków drapieżnych, których pożyteczna rola pozostaje bezsprzeczna, należy zwrócić uwagę także na hemizoofagi, które mogą odżywiać się np. nasionami chwastów, przyczyniając się do ograniczenia ekspansji niepożądanej flory. Szczególną rolę w tej grupie odgrywają m.in. przedstawiciele rodzaju Harpalus (Twardowski 2010). Klasę recedentów reprezentowały dwa gatunki zoofagiczne: Carabus violaceus L. oraz Abax carinatus (Duft.). Najliczniej prezentowała się klasa subrecedentów, do której zaliczono 11 gatunków, co może świadczyć o sprzyjających warunkach ekologicznych badanego siedliska, w którym przedstawiciele poszczególnych taksonów odnajdują tymczasowe nisze ekologiczne, pozwalające traktować plantacje wierzby wiciowej jako rezerwuar.

Analiza struktury troficznej wykazała 85,7\% udział gatunków zoofagicznych, do których zaliczono zoofagi małe (47,6\% zgrupowania) z rodzaju Nebria, Notiophilus, Asaphidion, Metallina, Pterostichus, Abax, Calathus oraz Limodromus, jak również zoofagi duże $(38,1 \%)$, szczególnie cenne w aspekcie ekologicznym, reprezentowane przez przedstawicieli rodzajów Carabus, Pterostichus i Abax. Do hemizoofagów zaliczono 3 gatunki, co stanowiło 14,3\% zgrupowania.

Zarówno w ujęciu jakościowym, jak i ilościowym przeważały gatunki dendrofilne $(66,7 \%$ zgrupowania), przy czym do typowo leśnych zaliczono 47,6\% gatunków, a do gatunków ekotonowych, częściowo związanych z zadrzewieniami - 19,1\%. Obecność drapieżników oraz gatunków drzewolubnych świadczy o dość dobrej kondycji ekologicznej badanego siedliska, jak również pozwala traktować plantacje wierzby wiciowej jako substytut biocenoz leśnych, przyczyniających się tym samym do wzbogacania bioróżnorodności danego ekosystemu.
Liczny udział gatunków charakterystycznych dla terenów otwartych $(33,3 \%)$ w plantacji $S$. viminalis potwierdza zdolności migracyjne biegaczowatych, które w miejscach zadrzewionych znajdują schronienie.

Struktura zoogeograficzna złożona była z 5 elementów. Najliczniejsze były elementy palearktyczne, które skupiały 11 gatunków (52,4\% zgrupowania) oraz eurosyberyjskie z 7 gatunkami (33,3\%). Pozostałe trzy elementy, tj.: euroarktyczny, europejskiej prowincji leśnej oraz górskiej europejskiej prowincji leśnej reprezentowane były przez pojedyncze gatunki, których udział dla każdej z grup zoogeograficznych wyniósł 4,7\% zgrupowania.

W 2011 roku odłowiono 297 kusakowatych zaklasyfikowanych do 24 rodzajów i 43 gatunków, zaś w 2012 roku było to 298 okazów z 14 rodzajów reprezentujących 24 gatunki (tab. 3 ).

Klasę eudominantów reprezentowało 5 gatunków, przy czym $3 \mathrm{z}$ nich (Philonthus addendus Sharp, P. decorus Grav. oraz P. succicola Thoms.) były wspólne dla obydwu sezonów badawczych. Burakowski i wsp. (1980) opisuje te gatunki jako rzadkie i sporadycznie spotykane w skali kraju. Jednak nowsze badania terenów zadrzewionych Polski południowo-wschodniej dowodza, że są to gatunki dość liczne, które podobnie jak na plantacji wikliny, występują również w terenach zadrzewionych Podkarpacia, gdzie zaliczone zostały do tej samej klasy dominacji (Konieczna i Czerniakowski 2010; Konieczna i wsp. 2012). P. decorus Grav., będący gatunkiem leśnym, został wykazany na plantacji wierzby także przez Boháč i wsp. (2007). Pozostałymi eudominantami były Omalium rivulare (Payk.) w 2011 r. i Drusilla canaliculata (F.) w 2012 r. W klasie dominantów wyróżniono jeden gatunek wspólny Aleochara curtula Goeze. Ten parazytoid uznawany jest za cennego regulatora liczebności szkodliwych agrofagów, przede wszystkim fitofagicznych muchówek z rodzaju Delia (Anthomyiidae), a także Musca domestica 
(Muscidae) i licznych gatunków z rodzin Calliphoridae i Sarcophagidae (Maus i wsp. 1998). Pozostałymi dominantami były Drusilla canaliculata (F.) w 2011 r. oraz Omalium rivulare (Payk.) w 2012 r. W klasie subdominantów wyróżniono 4 gatunki, przy czym tylko Oxypoda acuminata (Steph.) występował w obydwu latach badań. Pozostałe trzy zostały zaobserwowane w 2011 roku. Badania wykazały obecność 8 gatunków zaliczonych do klasy recedentów oraz 33 subrecedentów. Występowanie większej liczby gatunków o niskiej liczebności (recedenci i subrecedenci) świadczy o wewnętrznym zróżnicowaniu badanej biocenozy (Trojan 1998). Struktura jakościowoilościowa odłowionych Staphylinidae wyraźnie przedstawia fluktuacje liczebności gatunków w poszczególnych klasach dominacji na przestrzeni dwóch lat badań. Niemalże identyczna liczba odnotowanych okazów (różnica jednego osobnika) nie koreluje z liczbą gatunków. Różnice te mogą być wywołane czynnikami atmosferycznymi (temperatura, opady), czynnikami biotycznymi (dostęp do pożywienia, możliwości penetracji terenu przez kusakowate), czynnikami związanymi z właściwościami gleby, jak i antropogenicznymi.

Odłowione kusakowate zaklasyfikowano do 4 elementów zoogeograficznych. Najliczniej (26 taksonów i 52\% zgrupowania) reprezentowane były gatunki o zasiegu palearktycznym oraz gatunki europejskie (13 przedstawicieli i $26 \%$ zgrupowania). Mniej było reprezentantów elementu holarktycznego (10 gatunków i 20\% zgrupowania). Zasięg kosmopolityczny reprezentowała Aleochara curtula Goeze ( $2 \%$ zgrupowania). Jak podaje Szujecki (2008), w krajowej faunie przeważają gatunki o zasięgu europejskim i eurosyberyjskim, których udział $\mathrm{w}$ biocenozach zbliżonych do naturalnych wynosi ponad $50 \%$. Tereny zmienione antropogenicznie, m.in. agrocenozy lub wprowadzane do środowiska naturalnego sztuczne nasadzenia $\mathrm{w}$ postaci plantacji wikliny, predysponują występowanie gatunków palearktycznych, eurytopowych, o szerokim spektrum walencji ekologicznej. Różnorodność biotopów obrzeży miasta, mozaikowatość szaty roślinnej, zmienność warunków glebowych i mikroklimatycznych powoduje, że oprócz pospolitych gatunków Staphylinidae, w takich środowiskach występują także gatunki rzadko obserwowane.

Specjalizacja pokarmowa kusakowatych wykazuje zróżnicowanie, co ma istotny wpływ na ich znaczenie $\mathrm{w}$ biocenozie. Analiza struktury troficznej odłowionych Staphylinidae złożona była z 4 elementów. Największy udział miały gatunki zoofagiczne, które stanowiły $42 \%$ zgrupowania (21 taksonów). Większość dorosłych kusakowatych to drapieżcy, których bazę pokarmowa, podobnie jak biegaczowatych, stanowią różne stadia rozwojowe m.in. agrofagów zaliczanych do motyli, chrząszczy, muchówek, pluskwiaków, a także szkodliwych bezkregowców, m.in. ślimaków. Wśród zoofagicznych Staphylinidae można wyróżnić różne grupy ekologiczne. Do gatunków żyjących w szczątkach organicznych i atakujących larwy oraz imagines koprofagów, głównie chrząszczy i muchówek, można zaliczyć Ontholestes tesselatus (Geoffr.), czy niektórych przedstawicieli rodzaju Philonthus (m.in. P. succicola Thoms.). Gatunkami ściółkowymi, penetrującymi glebę w poszukiwaniu larw i poczwarek są m.in.
Staphylinus erythropterus L. oraz Philonthus decorus (Grav). Do aktywnie polujących chrząszczy, przemierzających powierzchniowe warstwy gleby, w tym także strefę roślin zielnych, należą gatunki odżywiające się małymi owadami, m.in. mszycami, zwłaszcza ich stadiami preimaginalnymi. Charakterystycznymi przedstawicielami tej grupy są m.in. dorosłe osobniki z rodzaju Paederus, Othius i Philonthus. Gatunkami, które prowadzą zarówno drapieżny tryb życia, jak i wykazuja preferencje grzybolubne, sa przedstawiciele rodzaju Tachyporus. Ta hemizoofagiczna grupa reprezentowana była przez 5 gatunków, co stanowiło $10 \%$ zgrupowania.

Szczególną formą zoofagii jest pasożytnictwo, które u kusakowatych reprezentują przedstawiciele rodzaju Aleochara. W tej grupie troficznej wykazano jeden gatunek (A. curtula Grav.), którego udział stanowił 2\% zgrupowania.

Wśród kusakowatych odnotowano także gatunki saprofagiczne (14 gatunków i 28\% zgrupowania), sapromycetofagiczne (4 gatunki i $8 \%$ zgrupowania) oraz mycetofagiczne (6 gatunków i 12\% zgrupowania). Obecność w środowisku organizmów detrytofilnych jest równie cenna, co obecność drapieżników. Rozkład związków złożonych na substancje proste, które są dostępne dla wody, umożliwia wykorzystanie tych pierwiastków przez rośliny. Konsekwencją tego procesu jest zwiększenie ilości próchnicy, co poprawia regenerację płodności gleby (Żółtkowski 1953).

Kusakowate będąc stałym komponentem agrocenoz, stanowią jedną $\mathrm{z}$ najważniejszych grup epigeicznych chrząszczy, a w niektórych przypadkach obserwuje się przewyższenie ich liczebności względem biegaczowatych (Newton i wsp. 2000).

Przeprowadzone odłowy wykazały obecność gatunków ujętych w "Czerwonej liście zwierząt ginących i zagrożonych" (Głowaciński 2002). Należą do nich Philonthus pseudovarians Strand (NT) oraz Tasgius morsitans (Rossi) (DD). Sporym zaskoczeniem jest obecność dwóch gatunków silnie związanych $\mathrm{z}$ naturalnymi lasami: P. mannerheimi Fauv. oraz Platydracus fulvipes (Scopoli). Do gatunków rzadko spotykanych należą także Omalium septentrionis Thoms., Anotylus rugifrons (Hochh.), A. mutator (Lohse) oraz P. rotundicolis (Ménétries).

\section{Wnioski / Conclusions}

1. Przekształcanie środowiska przyrodniczego bardzo często pociaga za sobą niekorzystne skutki. Prowadzone w Polsce badania ekologiczne i faunistyczne bezkręgowców wskazują na tendencje do zmniejszania się różnorodności gatunkowej. Głównymi powodami tego zjawiska są degradacja środowiska oraz zmniejszanie się powierzchni zajmowanej przez naturalne ekosystemy.

2. Ważną funkcją w utrzymaniu bioróżnorodności, zarówno agrocenoz, jak i urbicenoz jest pozostawianie różnego rodzaju enklaw zieleni w postaci zadrzewień i zakrzewień na terenach poddawanych ciagłej antropopresji. 
3. Wyniki obserwacji przedstawione w niniejszej publikacji dowodza, że nieużytkowane plantacje wikliny moga stanowić miejsca o korzystnych warunkach do rozwoju pożytecznej epigeicznej entomofauny chrząszczy biegaczowatych i kusakowatych.

\section{Podziękowania / Acknowledgements}

Autorzy składają podziękowania Panu dr inż. Tomaszowi Dudkowi z Uniwersytetu Rzeszowskiego za pomoc przy opracowaniu uzyskanych wyników pod względem statystycznym.

\section{Literatura / References}

Assing V., Schülke M. 2012. Staphylinidae I (exklusive Aleocharinae, Pselaphinae und Scydmaeninae). p. 397-450. In: Die Käfer Mitteleuropas (H. Freude, W. Harde, A. Lohse, B. Klausnitzer, eds.). Band 4. Spektrum Akademischer Verlag, Heidelberg, 560 pp.

Boháč J. 1999. Staphylinid beetles as a bioindicators. Agric. Ecosys. Environ. 74: 357-372.

Boháč J., Cejlak I., Moudrý J., Kohout P., Wotanová K. 2007. Communities of beetles in plantations of fast growing plant species for energetic purposes. Entomol. Rom. 12: 213-221.

Burakowski B., Mroczkowski M., Stefańska J. (red.). 1973. Chrząszcze Coleoptera, Biegaczowate - Carabidae. Katalog Fauny Polski. PWN, Warszawa, XXIII, 2, 233 ss.

Burakowski B., Mroczkowski M., Stefańska J. (red.). 1974. Chrząszcze Coleoptera, Biegaczowate - Carabidae. Katalog Fauny Polski. PWN, Warszawa, XXIII, 3, 430 ss.

Burakowski B., Mroczkowski M., Stefańska J. (red.). 1979. Chrząszcze Coleoptera, Kusakowate - Staphylinidae. Katalog Fauny Polski. PWN, Warszawa, XXIII, 6, 310 ss.

Burakowski B., Mroczkowski M., Stefańska J. (red.). 1980. Chrząszcze Coleoptera, Kusakowate - Staphylinidae. Katalog Fauny Polski. PWN, Warszawa, XXIII, 7, 272 ss.

Burakowski B., Mroczkowski M., Stefańska J. (red.). 1981. Chrząszcze Coleoptera, Kusakowate - Staphylinidae. Katalog Fauny Polski. PWN, Warszawa, XXIII, 8, 330 ss.

Czerniakowski Z.W., Olbrycht T. 2009. Ground beetles (Coleoptera, Carabidae) in the short-rotation biomass plantations. Zesz. Nauk. Południowo-Wschodniego Oddziału Polskiego Towarzystwa Inżynierii Ekologicznej z siedzibą w Rzeszowie i Polskiego Towarzystwa Gleboznawczego Oddział w Rzeszowie 11: 39-42.

Głowaciński Z. 2002. Czerwona lista zwierząt ginących i zagrożonych w Polsce. PAN IOP, Kraków, 229 ss.

Jahnová Z., Boháč J. 2009. Communities of epigeic beetles (Coleoptera: Carabidae, Staphylinidae) on plantations of fast growing grasses. p. 38-41. In: “Communications and Abstracts” (T. Soldán, M. Papáček, J. Boháč, eds.). SIEEC 21, June 28-July 3, 2009. University of South Bohemia, České Budějovice, 96 pp.

Jahnová Z., Boháč J. 2011. Společenstva epigeických brouků (Coleoptera: Carabidae, Staphylinidae) v porostech bylin pro energetické účely (Communities of epigeic beetles (Coleoptera: Carabidae, Staphylinidae) on the plantations of herbs for energetic purposes). Acta Mus. Beskid. 3: 133-143.

Kasprzak K., Niedbała W. 1981. Wskaźniki biocenotyczne stosowane przy porządkowaniu i analizie danych w badanych ilościowych. s. 397-409. W: „Metody stosowane w zoologii gleby” (M. Górny, L. Grüm, red.). PWN, Kraków, 483 ss.

Konieczna K., Czerniakowski Z. 2010. Drapieżne kusakowate (Coleoptera: Staphylinidae) w wybranych biotopach południowowschodniej Polski. [Predacious Staphylinidae in selected biotopes of south-eastern Poland]. Prog. Plant Prot./Post. Ochr. Roślin 50 (3): 1499-1503.

Konieczna K., Melke A., Olbrycht T. 2012. Bioróżnorodność drapieżnych biegaczowatych (Col., Carabidae) i kusakowatych (Col., Staphylinidae) zasiedlających pole uprawne i zadrzewienie śródpolne. [Biodiversity of predacious ground beetles (Col., Carabidae) and rove beetles (Col., Staphylinidae) assemblages in field and field coppice]. Prog. Plant. Prot./Post. Ochr. Roślin 52 (2): $340-346$.

Kosewska A., Nietupski M., Laszczak-Dawid A., Ciepielewska D. 2010. Biegaczowate (Coleoptera: Carabidae) zasiedlające uprawy wierzby krzewiastej Salix spp. [Ground beetles (Coleoptera: Carabidae) inhabiting shrub willow plantations]. Prog. Plant. Prot./Post. Ochr. Roślin 50 (30): 1504-1510.

Leśniak A. 1984. Biegaczowate (Carabidae, Col.) lasów Karkonoskiego Parku Narodowego. Prace Karkon. Tow. Nauk. 41: 37-70.

Leśniak A. 1987. Zoogeographical analysis of the Carabidae (Coleoptera) of Poland. Fragm. Faun. 30 (17): 297-312.

Mast B., Graeff Hönninger S., Claupein W. 2012. Evaluation of Carabid beetle diversity in different bioenergy cropping systems. Sustainable Agric. Res. 1 (2): 127-140.

Maus Ch., Mittmann B., Peschke K. 1998. Host records of parasitoid Aleochara Gravenhorst species (Coleoptera, Staphylinidae) attacking puparia of cyclorrhapheous Diptera. Deut. Entomol. Z. 45 (2): 231-254.

Newton A.F., Thayer M.K., Ashe J.S., Chandler D.S. 2000. Staphylinidae. p. 272-418. In: “American Beetles” (R.H. Arnett, M.C. Thomas, eds.). Vol. 1. Boca Raton, Florida, CRC Press, 464 pp.

Olbrycht T., Wiech K. 2004. Skład gatunkowy oraz struktura ilościowo-jakościowa drapieżnych chrząszczy z rodzin biegaczowatych (Col. Carabidae) i kusakowatych (Col. Staphylinidae) w uprawach roślin strączkowych w mieszankach ze zbożami. [Composition of carabid and rove beetle species occurring in mixed cropping of some legumes and small grains]. Prog. Plant Prot./Post. Ochr. Roślin 44 (2): 994-997.

Sądej W., Ciepielewska D., Pomianowska E. 1997. Entomofauna wiesiołka dwuletniego (Oenothera biennia L.) i jego rola w grocenozie. Rośliny Oleiste - Oilseed Crops 18: 366-370.

Sądej W., Waleryś G., Tworkowski J. 2007. Rośliny alternatywne czynnikiem stymulującym występowanie zoofagów. [Alternative plants as a factor stimulating occurrence of entomophages]. Prog. Plant. Prot./Post. Ochr. Roślin 47 (4): 202-211.

Stachowiak M. 2008. Przegląd systematyczny biegaczowatych Polski (Coleoptera, Carabidae) - wersja skrócona. http://www. entomo.pl/coleoptera/carabidae/index.php, dostęp: 17.02.2013.

Staniec B. 2004. Kusakowate (Staphylinidae). s. 153-155, 162-176. W: „Fauna Polski - charakterystyka i wykaz gatunków” (W. Bogdanowicz, E. Chudzicka, I. Pilipiuk, E. Skibińska, red.). T. I. Muzeum i Instytut Zoologii PAN, Warszawa, 509 ss. 
Št’astná P. 2012. Diversity of ground beetles (Carabidae) in the plantation of fast growing trees. Acta Univ. Agric. Silvic. Mendel. Brun. LX (6): 309-316.

Szczukowski S., Tworkowski J., Wiwart M., Przyborowski J. 1998. Wiklina (Salix sp.). Uprawa i możliwości wykorzystywania. ART, Olsztyn, 59 ss.

Szujecki A. 2008. Kusakowate - Staphylinidae, Wstęp do podrodziny: Micropeplinae, Piestinae, Osoriinae, Pseudopsiinae, Phloeocharinae, Olisthaerinae, Proteininae, Omaliinae, Oxytelinae, Oxyporinae. Klucze do oznaczania owadów Polski. Polskie Towarzystwo Entomologiczne, Toruń, XIX, 24a, 229 ss.

Szyszko J. 2002. Carabids as an efficient indicator of the quality and functioning of forest ecosystems useful in forestry management. p. 301-318. In: "How to protect or what we know about Carabid beetles from knowledge to application - from Wijster (1969) to Tuvczmo (2001)" (J. Szyszko, P.J. den Boer, Th. Bauer, eds). Warsaw Agricultural University Press, 378 pp.

Trojan P. 1998. Nowe perspektywy w badaniach faunistycznych. s. 137-155. W: Materiały Zjazdowe 43. Zjazdu Polskiego Towarzystwa Entomologicznego. Poznań, 4-6 września 1998, Wiad. Entomol. 17, Supl., 207 ss.

Twardowski J. 2010. Wpływ uproszczeń w uprawie roli pod pszenicę ozimą na zgrupowania stawonogów epigeicznych i glebowych. Monografie CVII, UP, Wrocław, 141 ss.

Waleryś G., Sądej W., Kosewska A. 2008. Uprawa wierzby krzewiastej Salix spp. miejscem bytowania drapieżnych biegaczowatych Carabidae. Fragm. Agron. 25, 2 (98): 158-169.

Żółtowski Z. 1953. Entomologia sanitarna. Ministerstwo Obrony Narodowej, Warszawa, 228 ss. 